\title{
Chemiluminescent and Bioluminescent Assays for Polyadenylic Acid and Applications to DNA Probe Assay and Immunoassay
}

\author{
Hidetoshi Arakawa, Masako Maeda and Akio Tsuj \\ School of Pharmaceutical Sciences, Showa University, Hatanodai, Shinagawa, Tokyo 142, Japan
}

\begin{abstract}
We developed a chemiluminescent (CL) assay for polyadenylic acid (poly A) based on the enzymatic cycling reaction following the conversion to ATP by pyruvate kinase/polynucleotide phosphoryrase enzyme reaction. Poly A was also measured with the bioluminescent (BL) assay using luciferase from firefly Photinus pyralis. The detection limits of poly $\mathrm{A}$ by $\mathrm{CL}$ and $\mathrm{BL}$ assay were $10 \mathrm{amol}$ and $2 \mathrm{amol}$, respectively. We prepared the biotinylated poly $\mathrm{A}$ using biotin hydrazide and glutaraldehyde as a bifunctional coupling reagent to apply the poly $\mathrm{A}$ assay to a general avidin-biotin reaction system. When the $C L$ assay and the $B L$ assay of biotinylated poly $A$ are applied to the DNA probe assay of $\lambda$ phage DNA and the immunoassay of thyroid-stimulating hormone (TSH) using avidin-biotin reaction as detection system, $500 \mathrm{pg}^{2}$ assay-1 well of $\lambda$-phage DNA and $3 \mu \mathrm{U} \mathrm{ml}^{-1}$ of TSH were determined.
\end{abstract}

Keywords Chemiluminescence, bioluminescence, polyadenylic acid, DNA probe assay, immunoassay

A great number of alternative substances to radio'isotopes have been used in immunoassay and DNA probe assays: fluorescent and luminescent compounds, free radicals, and metals are used as labels. Recently, Vary et al. ${ }^{1}$ reported a non-isotopic DNA probe assay using polyadenylic acid (poly A) as a label. The labeled poly A was measured by bioluminescent (BL) assay using luciferase from firefly Photinus pyralis after converting to ATP by the coupled enzyme reaction of polynucleotide phosphoryrase (PNP) and pyruvate kinase (PK).

We have developed two chemiluminescent (CL) methods for the assay of ATP: one is the CL method using hexokinase (HK)/glucose-6-phosphate dehydrogenase (G6PDH) as catalytic enzymes and D-glucose/ $\mathrm{NADP}^{+}$as substrates, and the other one is the enhanced CL method based on the enzymatic cycling reaction using HK and PK. In both methods, NADPH generated by the enzymatic reaction is finally measured by the CL assay using 1-methoxy-5-methylphenazinium methylsulfate (1-MPMS)/isoluminol(IL)/microperoxidase (mPOD). ${ }^{2}$

We have recently developed a CL assay of poly $A$ based on the enzymatic cycling reaction of ATP and its application to a CL DNA probe assay using biotinylated poly $A$ as label. We also developed a BL immunoassay for human thyroid-stimulating hormone (hTSH) using the biotinylated poly $\mathrm{A}$ as label and luciferase reaction as the detection system.

\section{Experimental}

Materials

Poly A (approximatly 1500 mer), PNP (EC 2.7.7.8),
PK (EC 2.7.1.40), HK (EC 2.7.1.2), G6PDH (EC 1.1.1.49), NADP, ATP, D-biotin- $N$-hydroxysuccinimide ester and D-biotinyl- $\varepsilon$-aminocaproic acid hydrazide (biotin-X-hydrazide), hTSH, rabbit anti-biotin antiserum and goat anti-rabbit IgG antiserum were purchased from Boehringer Mannheim-Yamanouchi Co. (Tokyo, Japan) and Calbiochem Co. (La Jolla, USA). A recombinant firefly luciferase by over expression in $\mathrm{E}$. coli of the cDNA from Luciola cruciate was generously donated by Kikkoman Co. (Chiba, Japan).

D-Luciferin and microperoxidase (m-POD) were from Sigma Chemical Co. (St. Louis, USA), isoluminol (IL) from Tokyo Chemical Industry Co. (Tokyo, Japan), $\lambda$ phage DNA (bacteriophage cI 857 S7) from Takara Co. (Kyoto, Japan), avidin and glutaraldehyde from Wako Pure Chemical Industries Ltd. (Osaka, Japan). Polyclonal rabbit anti-hTSH antiserum was generously donated by Chen (Shanghai Second Medical College, China). The mouse monoclonal anti-hTSH antiserum coated plate was also kindly donated by Fujirebio Inc. (Tokyo, Japan). 1-MPMS and other chemicals were of reagent grade.

\section{Instruments}

An Aloka luminescence reader Model (Aloka Co., Tokyo, Japan) was used for the measurement of chemiluminescence. An ELISA reader was used.

\section{Methods}

$C L$ assay of ATP. To an assay tube, $100 \mu \mathrm{l}$ of ATP standard or sample solution, $50 \mu \mathrm{l}$ of the solution containing $160 \mathrm{U} \mathrm{ml}^{-1} \mathrm{PK}$ and $75 \mu \mathrm{mol} \mathrm{ml}^{-1} \mathrm{PEP}, 50 \mu \mathrm{l}$ of the $400 \mathrm{mU} \mathrm{ml}^{-1} \mathrm{HK}$ solution, $250 \mu \mathrm{l}$ of the $0.5 \mathrm{mmol} \mathrm{l}^{-1}$ $\mathrm{MgCl}_{2}$ solution and $20 \mu \mathrm{l}$ of the $0.6 \mathrm{moll}^{-1} \mathrm{D}$-glucose 
solution were added and then solutions were incubated overnight at $4^{\circ} \mathrm{C}$. After incubation, $250 \mu \mathrm{l}$ of the $0.05 \mathrm{mmol} \mathrm{l}^{-1} \mathrm{NADP}^{+}$solution and $50 \mu \mathrm{l}$ of $250 \mathrm{mU} \mathrm{ml}^{-1}$ G6PDH solution were added and solutions were incubated again for $60 \mathrm{~min}$ at $30^{\circ} \mathrm{C}$. After incubation, $500 \mu \mathrm{l}$ of the $5 \times 10^{-6} \mathrm{~mol} \mathrm{l}^{-1} 1$-MPMS solution was added: this mixture was incubated for $30 \mathrm{~s}$ at room temperature. The CL reaction was initiated with addition of $500 \mu \mathrm{l}$ of the $\mathrm{CL}$ reagent solution $(1: 1 \mathrm{v} / \mathrm{v})$ mixture of $2.4 \times$ $10^{-4} \mathrm{~mol} \mathrm{l}^{-1} \mathrm{IL}$ solution in $0.8 \mathrm{~mol} \mathrm{l}^{-1}$ carbonate buffer (pH 9.5), and $1 \times 10^{-6} \mathrm{~mol}^{-1} \mathrm{~m}-\mathrm{POD}$ solution and the $6 \mathrm{~s}$ integral $\mathrm{CL}$ measurements were performed $15 \mathrm{~s}$ after the addition of $\mathrm{CL}$ reagent with an Aloka luminescence reader.

$C L$ assay of poly $A$. To an assay tube, $10 \mu \mathrm{l}$ of poly $\mathrm{A}$ solution (containing $10 \mathrm{pg}-10 \mathrm{ng}$ ), $20 \mu \mathrm{l}$ of a reagent solution containing $10 \mathrm{U} \mathrm{ml}^{-1} \mathrm{PNP}, 100 \mathrm{U} \mathrm{ml}^{-1} \mathrm{PK}$, $5 \mathrm{U} \mathrm{ml}^{-1} \mathrm{HK}, 30 \mathrm{mmol} \mathrm{l}^{-1}$ PEP, $1 \mathrm{mmol} \mathrm{l}^{-1} \mathrm{MgCl}_{2}$, $10 \mathrm{mmol} \mathrm{l}^{-1} \mathrm{Na}_{2} \mathrm{HPO}_{4}$ and $0.1 \mathrm{moll}^{-1}$ Tris- $\mathrm{HCl}$ buffer (pH 8.5), and $20 \mu \mathrm{l}$ of $0.6 \mathrm{~mol}^{-1} \mathrm{D}$-glucose were added. After incubation for $2 \mathrm{~h}$ at $37^{\circ} \mathrm{C}$ or overnight at $4^{\circ} \mathrm{C}$, $250 \mu \mathrm{l}$ of the $0.05 \mathrm{mmol}^{-1} \mathrm{NADP}^{+}$and $50 \mu \mathrm{l}$ of the $250 \mathrm{mU} \mathrm{ml}^{-1} \mathrm{G} 6 \mathrm{PDH}$ solution were added and incubated as described above. The CL intensity was measured after addition of the $C L$ reagent solution.

$B L$ assay of poly $A$. The BL assay of poly A was carried out according to the procedure of Vary et al. ${ }^{1}$

Preparation of biotinylated poly $A$. Biotinylated poly A was prepared by the modified procedure established previously in this laboratory. ${ }^{3}$

A $1.25 \mathrm{ml}$ of $10 \mathrm{mg} \mathrm{ml}^{-1}$ biotin-X-hydrazide and $1.5 \mathrm{ml}$ of $0.05 \%$ glutaraldehyde were added to $2.5 \mathrm{ml}$ of $1 \mathrm{mg}$ $\mathrm{ml}^{-1}$ poly A. After incubation for $10 \mathrm{~min}$ at $37^{\circ} \mathrm{C}$, $0.58 \mathrm{ml}$ of $3 \mathrm{~mol} \mathrm{l}^{-1}$ sodium acetate and $14.6 \mathrm{ml}$ of cold ethanol were added to the reaction solution. The resultant solution was cooled at $-20^{\circ} \mathrm{C}$ overnight. After centrifuging for $10 \mathrm{~min}$ at room temperature, the precipitated biotinylated poly $A$ was washed with cold $80 \%$ ethanol, dried in vacuo for $2 \mathrm{~h}$, redissolved in $10 \mathrm{ml}$ of cold water and then stored at $-20^{\circ} \mathrm{C}$ until use.

Preparation of biotinylated polyclonal anti-hTSH antibody.

The IgG fraction was obtained from polyclonal rabbit anti-hTSH antiserum by ammonium sulfate precipitation. The obtained IgG fraction was conjugated with biotin- $N$-hydroxy succinimide ester according to the method of Barnard et al. ${ }^{4}$ The biotinylated IgG of polyclonal anti-hTSH antibody was purified by the usual chromatographic procedure with Sephadex G-25.

Enzyme immunoassay (EIA) of biotin. EIA of biotin was developed in order to determine biotin in the biotinylated poly A. Alkaline phosphatase (ALP)biotin conjugate was prepared in the manner mentioned above and purified with Sephadex G-25 column chromatography $(1 \mathrm{~cm} \times 50 \mathrm{~cm})$. A $10 \mu 1$ of the sample solution, $100 \mu \mathrm{l}$ of the diluted ALP-biotin conjugate solution $(1: 2000)$ and $100 \mu 1$ of 5000 -fold diluted antibiotin antiserum were added to a microtiterplate coated with goat anti-rabbit IgG antiserum. The plate was left overnight at $4^{\circ} \mathrm{C}$, washed three times with $0.05 \mathrm{~mol} \mathrm{l}^{-1}$ phosphate-saline buffer (pH 7.0) (PBS) and the ALP activity on the well was measured using $p$-nitrophenyl phosphate as substrate by ELISA reader in the usual manner. ${ }^{5}$

$C L D N A$ probe assay for $\lambda-D N A$. The DNA probe assay for $\lambda$-DNA was carried out according to the procedure reported previously in this laboratory. ${ }^{3}$ The heat-denatured DNA was diluted with a coating buffer consisting of $8 \mathrm{mmol} \mathrm{l}^{-1} \mathrm{Na}_{2} \mathrm{HPO}_{4}, 1.5 \mathrm{mmol} \mathrm{l}^{-1} \mathrm{KH}_{2} \mathrm{PO}_{4}$, $137 \mathrm{mmol}^{-1} \mathrm{NaCl}$ and $0.1 \mathrm{~mol} \mathrm{l}^{-1} \mathrm{MgCl}_{2}$ (pH 7.2). A $200 \mu \mathrm{l}$ portion of the diluted DNA solution (500 pg$100 \mathrm{ng}$ ) was transferred into each well of a microtiter plate and incubated overnight at room temperature. After removal of the sample solution by aspiration, $200 \mu \mathrm{l}$ of prehybridization solution (4XSSC consisted of $0.6 \mathrm{M} \mathrm{NaCl}$ and $0.06 \mathrm{M}$ sodium citrate, $0.06 \%$ polyvinylpyrrolidone (PVP), Ficoll and bovine serum albumin (BSA), heat- denatured calf thymus DNA $50 \mu \mathrm{g} \mathrm{ml}^{-1}$ ) was added to each well. The plate was covered with a shield and incubated for $1 \mathrm{~h}$ at $65^{\circ} \mathrm{C}$, floating in a water bath. The prehybridization solution was removed by aspiration, then $200 \mu \mathrm{l}$ of hybridization solution consisting of prehybridization solution containing $10 \%$ dextran sulfate and $1 \mu \mathrm{g} \mathrm{ml}^{-1}$ biotin labeled $\lambda$-DNA probe) was added; then the plate was left overnight at $65^{\circ} \mathrm{C}$. After aspiration of the solution, each well was incubated with $2 \times S S C$ at $65^{\circ} \mathrm{C}$ for $30 \mathrm{~min}$, and then washed three times with $200 \mu \mathrm{l}$ of PBS. The plate was left for $30 \mathrm{~min}$ at room temperature, followed by addition of $100 \mu \mathrm{l}$ of $0.02 \mathrm{mg} \mathrm{ml}^{-1}$ avidin solution. After incubation, the plate was washed three times with $300 \mu$ of PBS and incubated for $30 \mathrm{~min}$ at room temperature with addition of $100 \mu \mathrm{l}$ of 100 -fold diluted biotinylated poly A solution. After incubation, the plate was washed two times with $300 \mu \mathrm{l}$ of PBS and then $300 \mu \mathrm{l}$ of $0.1 \mathrm{~mol} \mathrm{l}^{-1}$ Tris- $\mathrm{HCl}$ buffer (pH 8.0). After addition of $20 \mu \mathrm{l}$ of $0.1 \mathrm{~mol} \mathrm{l}^{-1}$ Tris- $\mathrm{HCl}$ buffer to each well, poly $\mathrm{A}$ bound on each well was measured with the modified CL assay of poly $A$ described above. Thus $40 \mu \mathrm{l}$ of reagent solution consisting of PNP, PK, HK, PEP, $\mathrm{MgCl}_{2}$ and $\mathrm{Na}_{2} \mathrm{HPO}_{4}$ and $40 \mu \mathrm{l}$ of glucose solution were used, respectively. Other conditions (concentration of each reagent, volume of G6PDH solution and reaction time) were the same as the assay described above.

$B L$ or $C L$ immunoassay for hTSH. A hundred microliters of biotinylated polyclonal anti-hTSH antibody was added to each well coated with mouse monoclonal anti-hTSH antibody, followed by addition of $50 \mu 1$ of a TSH standard solution $\left(1-200 \mu \mathrm{U} \mathrm{ml}^{-1}\right)$ or sample solution. After incubation overnight at $4^{\circ} \mathrm{C}$ or for $2 \mathrm{~h}$ at $37^{\circ} \mathrm{C}$, the plate was washed three times with $300 \mu \mathrm{l}$ of PBS. After the reaction of avidinbiotinylated poly $A$, poly $A$ bound on each well was measured with the CL or BL assay of poly A described above. 


\section{Results and Discussion}

\section{Chemiluminescent assay of poly $A$}

Vary $e t$ al. ${ }^{1}$ reported a non-isotopic DNA probe assay using poly $\mathrm{A}$ as a label which was measured by a BL assay with firefly luciferase. In order to use the poly $A$ as a label, the primer-dependent PNP reaction was used in the presence of ADP following a TdT reaction for riboadenylation of DNA.

This labeling method is restricted to the DNA probe having a free hydroxy group of 3'-terminus. Therefore we have developed the procedure for coupling biotin to poly A by a simple chemical reaction using glutaraldehyde, and also the CL assay of biotinylated poly A using a CL assay of ATP. Then, we have established a CL DNA probe assay and an immunoassay

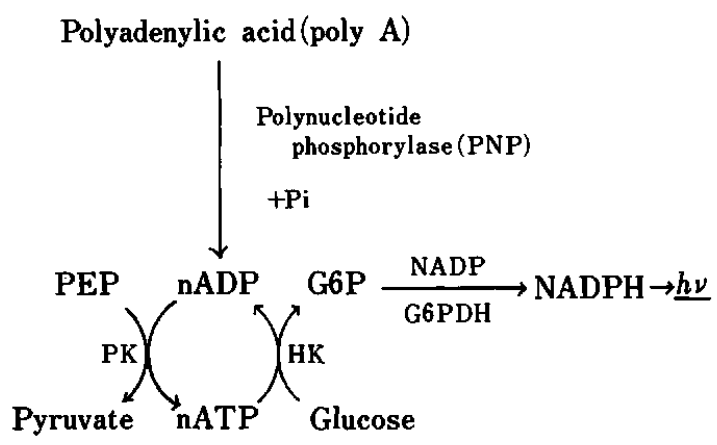

Fig. 1 Principle of chemiluminescent assay for poly A.

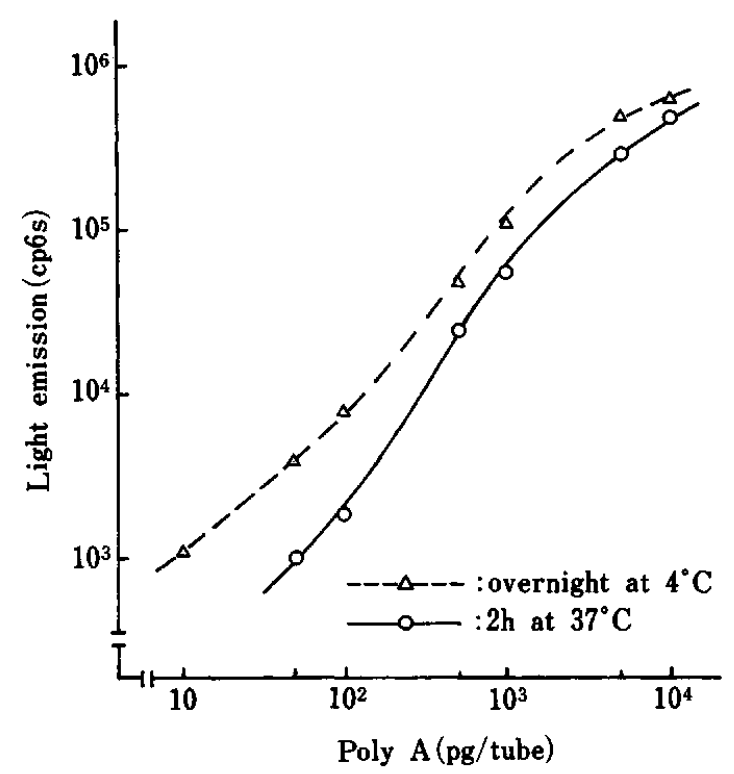

Fig. 2 Standard curves of poly A obtained by the chemiluminescent assay. based on the biotin-avidin detection system using biotinylated poly $A$ as a label. The principle of the CL assay of poly $A$ is illustrated in Fig. 1. Poly $A$ is converted to ADP by enzymatic reaction of PNP. The enzyme cycling reaction of ADP-ATP using HK and PK as coupled enzymes and PEP and D-glucose as substrates produces glucose-6-phosphate which reacts with NADP ${ }^{+}$ in the presence of G6PDH to yield NADPH. Then, NADPH generated is measured by the CL method using 1-MPMS/IL/m-POD system.

Various factors affecting on $\mathrm{CL}$ assay of poly $\mathrm{A}$, such as concentrations of reagents, reaction time and temperature, were examined according to the procedure of Vary et al.' The procedure was finally decided as described in Methods. Standard curves of poly A obtained by the CL method and the BL method of Vary et $a{ }^{1}{ }^{1}$ are shown in Figs. 2, and 3, respectively. The detection limits of poly A were 10 amol for the CL assay and 2 amol for the BL assay. The detection limit of ATP using the enzyme cycling method was $10 \mathrm{fmol}$ per assay corresponding to that of the BL assay.

Therefore the sensitivity of the CL assay of poly $\mathrm{A}$ is expected to be the same as that of the $\mathrm{BL}$ assay. However, the sensitivity of the CL assay was lower than that of the BL assay. It is thought that the enzyme cycling rate was low in this system.

\section{Biotinylation of poly $A$}

Biotin was labeled to poly A using glutaraldehyde as a coupling reagent according to the procedure reported previously. ${ }^{3}$ The number of biotin molecules bound to poly $\mathrm{A}$ was determined by the EIA of biotin. Table 1 shows the effects of the glutaraldehyde concentration on the binding ratio (number of biotin bound to poly A) and the CL activity of biotinylated poly $A$.

The number of biotin bound to poly $A$ increased with increasing concentration of glutaraldehyde. The activity of biotinylated poly $A$ measured by the $\mathrm{CL}$ assay decreased with increasing the concentration of glutaral-

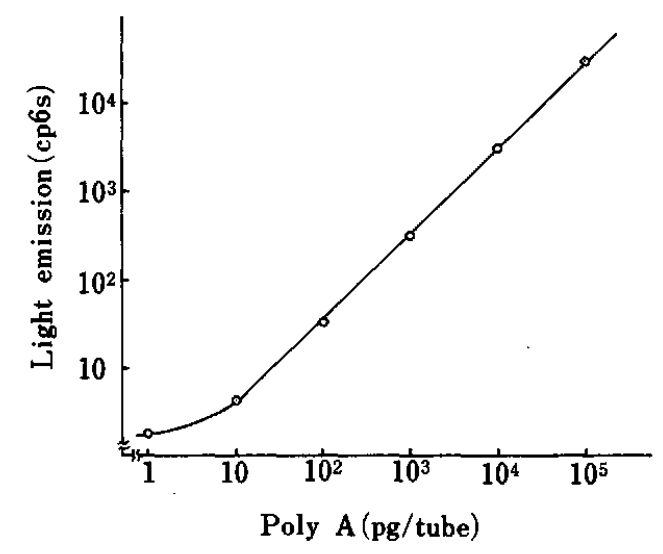

Fig. 3 Standard curve of poly A obtained by the bioluminescent assay. 
Table 1 Binding ratio of biotin to poly $A$ and activity of the biotinylated poly A prepared at various concentrations of glutaraldehyde

\begin{tabular}{ccc}
\hline $\begin{array}{c}\text { Glutaraldehyde, } \\
\%\end{array}$ & Binding ratio & $\begin{array}{c}\text { Activity poly } \mathbf{A}^{\mathrm{a}} \\
\%\end{array}$ \\
\hline 0.05 & 24 & 99 \\
0.1 & 48 & 91 \\
0.5 & 248 & 38 \\
1.0 & 298 & 37 \\
5.0 & 298 & 25 \\
\hline
\end{tabular}

a. Chemiluminescent intensity (CL activity) of the biotinylated poly A was measured as described in the Methods section. The value (\%) obtained in the absence of glutaraldehyde was taken as 100 .

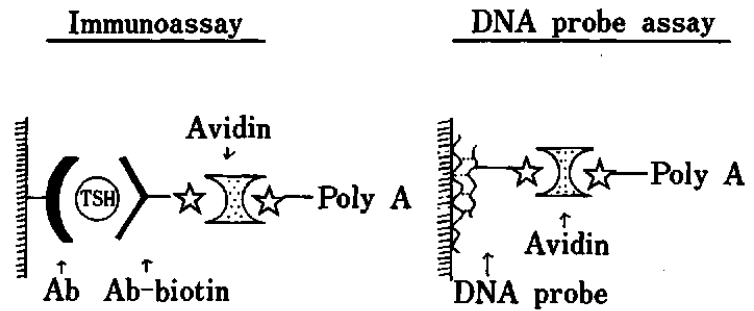

Fig. 4 Principle of chemiluminescent and bioluminescent methods of DNA probe assay and immunoassay.

dehyde. These results mean that the biotinylation of poly A results in inactivation proportional to the modified amino residues of adenylnucleotide. It is preferable to minimize the binding ratio of biotin to poly $\mathrm{A}$ in order to use the poly $\mathrm{A}$ as a probe on the avidinbiotin reaction system. Therefore, biotinylated poly A prepared with $0.5 \%$ of glutaraldehyde was used in the following experiment.

Application of biotinylated poly $A$ to the detection system using the biotin-avidin system

We applied the $\mathrm{CL}$ and $\mathrm{BL}$ assays of biotinylated poly $A$ to the DNA probe assay and immunoassay using biotin-avidin reaction as the detection system. Figure 4 illustrates the principle of the CL or BL DNA probe assay and immunoassay.

\section{Chemiluminescent DNA probe assay for $\lambda$-phage $D N A$}

Hybridization reaction with biotinylated $\lambda$-phage DNA was carried out according to the procedure established in a previous paper. ${ }^{3}$ In order to apply the previous method to the CL assay, several factors such as concentrations of avidin and biotinylated poly $\mathrm{A}$, reaction time, and reaction temperature, were examined, the procedure described in Methods was found to be most suitable. As shown in Fig. 5, a standard curve of $\lambda$-phage DNA was obtained in the range from $500 \mathrm{pg}$ to $50 \mathrm{ng} /$ well. The relative standard deviation for each point ranged from 1.6 to $6.6 \%(n=4)$.

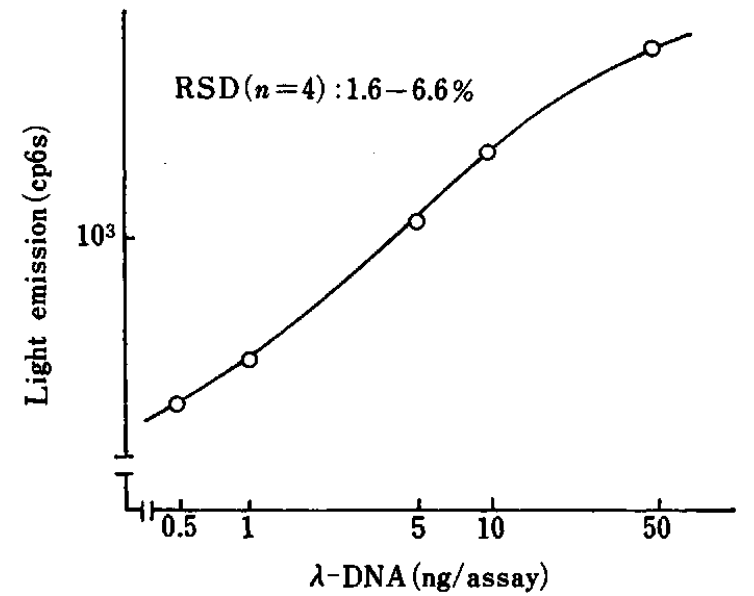

Fig. 5 Standard curve of $\lambda$-phage DNA obtained by the chemiluminescent DNA probe assay.
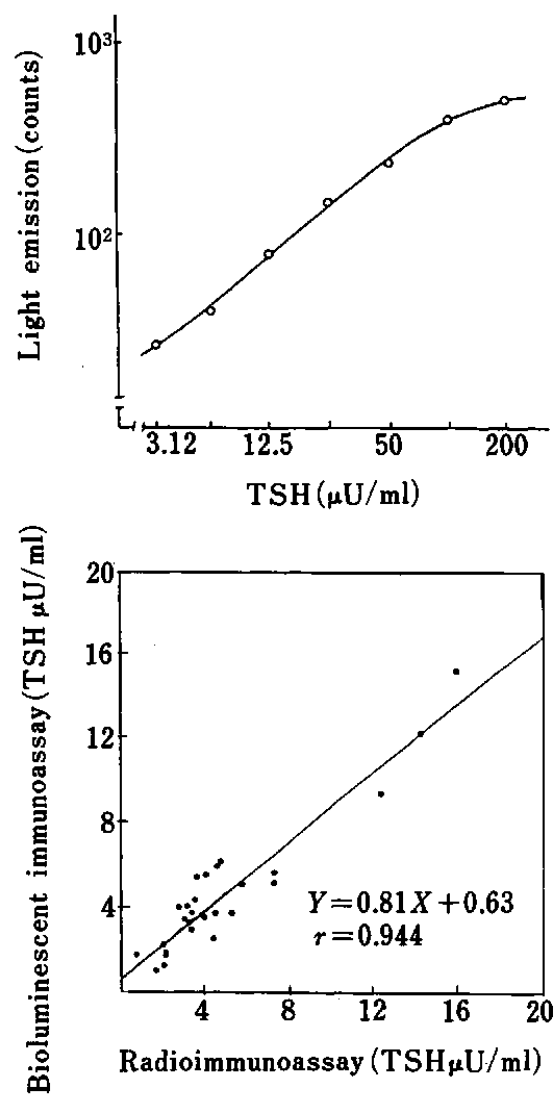

Fig. 6 Standard curve of TSH obtained by bioluminescent immunoassay and correlation between the bioluminescent immunoassay and the radioimmunoassay for hTSH.

\section{Bioluminescent immunoassay of hTSH}

A two-site immunometric assay of hTSH was carried out by using a microtiter plate coated with mouse monoclonal anti-hTSH antiserum and the biotinylated rabbit polyclonal anti-hTSH antiserum. To determine the optimum conditions for the EIA of hTSH, the concentrations of biotinylated antibody, avidin and 
biotinylated poly A were examined. The results suggested the procedure of the BL immunoassay for hTSH mentioned in Methods. The standard curve of hTSH is shown in Fig. 6. The detection limit of hTSH was $3 \mu \mathrm{U} \mathrm{ml}^{-1}$. To assess the reliability of the BL immunoassay of hTSH, TSH concentrations of serum samples were determined by this BL method and a commercial radioimmunoassay kit. As shown in Fig. 6, the results obtained by the proposed BL method $(Y)$ correlated well ( $r=0.944)$ with those by the radioimmunoassay $(X) ; Y=0.81 X+0.63$ for 27 serum samples. This proposed BL method will be applicable to the diagnosis of hypo- and hyperthyroidism. The CL assay of biotinylated poly $A$ was also examined to apply to the above system instead of the BL assay, but the reproducible results could not be obtained due to the inhibition on the enzyme cycling step by unknown substances in serum sample.

We have developed highly sensitive $\mathrm{CL}$ and $\mathrm{BL}$ assays of poly A. The detection limit of poly A was $2 \mathrm{amol}$ assay $^{-1}$ corresponding to $10 \mathrm{pg}^{2}$ assay $^{-1}$ poly $A$ (MW: ca. $5 \times 10^{5}$ ) for the BL assay and 10 amol for the CL assay.

The biotinylated poly $A$ was prepared by a simple chemical procedure using glutaraldehyde and could be applied to the general detection system based on the avidin-biotin reaction. The biotinylated poly A could be assayed by the CL and BL methods. The BL assay of biotinylated poly $A$ was more sensitive than the CL assay. These CL and BL assays could be applied to the DNA probe assay of $\lambda$-phage DNA and the immunoassay of hTSH using the avidin-biotin reaction as the detection system, respectively. The detection limits of $\lambda$-phage DNA and hTSH were $500 \mathrm{pg}^{\text {assay }}{ }^{-1}$ and $3 \mu \mathrm{U} \mathrm{ml}^{-1}$, respectively. In conclusion, these results shows that it is possible to develope sensitive and convenient DNA probe assays and immunoassays.

We are indebted to Kikkoman Co., for suppling the recombinant firefly luciferase, and also thank Fuji Revio Co., for suppling the mouse monoclonal anti-hTSH antiserum coated plate. We thank Professor R. Chen, Shanghai Second Medical College for supplying polyclonal rabbit anti-hTSH antiserum.

\section{References}

1. C. P. H. Vary, F. J. McMahon, F. P. Barbone and S. E. Diamond, Clin. Chem., 32, 1696 (1989).

2. A. Tsuji, M. Maeda and H. Arakawa, J. Biolumin. Chemilumin., 4, 454 (1989).

3. H. Arakawa, M. Maeda, A. Tsuji and T. Takahashi, Chem. Pharm. Bull., 37, 1831 (1989).

4. G. Barnard, E. A. Bayer, M. Wilchek, Y. Ami-Zaltsman and F. Kohen, Methods Enzymol., 133, 284 (1986).

5. C. T. Stanley, A. Johannsson and C. H. Self, J. Immunol. Methods, 83, 89 (1985).

(Received February 7, 1992)

(Accepted April 23, 1992) 